\title{
Multimedia Development Interactive Learning Using Problem Based Learning Adobe Flash Program to Increase Student's Motivation and Learning Outcomes in Salt Hydrolysis Material
}

\author{
Hariani Siregar \\ Department of Chemistry \\ Post Graduate Program, Medan State University \\ Medan, Indonesia \\ Ariani3siregar@gmail.com
}

\author{
Ajat Sudrajat \\ Department of Chemistry Education \\ Supervisor, State University of Medan \\ Medan, Indonesia
}

\begin{abstract}
This study aims to determine the feasibility of interactive multimedia as a learning medium in improving student motivation and learning outcomes in salt hydrolysis material. The population in this study were all class XI Negeri 1 Barumun Tengah, Padang Lawas District TA 2017/2018 which consisted of 7 classes and each class consisted of 25 people. While the research sample was selected using purposive random sampling technique. This study uses an experimental method, by teaching using (1) PBL-based interactive learning multimedia (2) DI-based learning media. The research steps include (a) preparation of syllabus and RPP, (b) teaching using PBL-based interactive learning multimedia and DI-based learning media (c) evaluation of student learning outcomes test sheets (pretest posttest). Data analysis using two-way variant analysis (anova two ways).
\end{abstract}

Keywords: Multimedia learning, PBL learning model, DI learning model, Adobe Flash, student learning outcomes, student learning motivation, Salt Hydrolysis

\section{INTRODUCTION}

In the learning methodology there are two most prominent aspects of the model and learning media as teaching aids. Various aspects that must be considered in choosing media include; (1) learning objectives, (2) types assignment, (3) student response expected after learning is completed and, (4) learning context including student characteristics (arsyad, 2011).

Learning media that is used appropriately can make abstract things concrete and complex things can be simplified so that students' understanding of a material can be improved (Basri, 2013).

Chemistry learning is still regarded as the most difficult lesson compared to other sciences. This is similar to that conveyed by Wiseman (in Pusparini, 2009) that chemistry is one of the most difficult lessons for most middle school students and students. Learning. Chemistry learning difficulties mainly lie in understanding macroscopy and the use of chemical symbols (Sudria, 2006).
Hydrolysis is one of the most demanding chemical studies in the study of macroscopic, microscopic and symbolic aspects. Hydrolysis in high school is still taught through lecture methods and / or discussions to memorize most of the concepts of hydrolysis (Sudarsana, 2010).

Developing computer-based interactive learning programs can facilitate the learning of chemical aspects macroscopically (concrete properties), microscopic (invisible particles of matter) and symbolic (chemical formulas for the representation of particle matter as substance identities). Computers can be programmed to provide feedback according to the desired communication interaction design via video. Computer-assisted learning can visualize static and dynamic microscopic aspects and present their relationship with macroscopic and symbolic aspects. Computer-assisted interactive learning media is able to present abstract concepts to be more concrete and more interesting. With interesting learning, it is expected to be able to increase the activities and learning outcomes of students. This statement was supported by Sirodjuddin (2007), Rahmawati (2006), Pusparini (2009) and Kirna (2010) who found that computer-assisted learning can increase students' learning activities and outcomes.

Sudarsana (2010) has successfully created a computeraided interactive learning program for the topic of hydrolysis that accommodates the integration of aspects of macroscopic, microscopic and symbolic chemistry.

Multimedia provides information for students in a simple way, however, interactive multimedia gives users control of information and ensures their participation. Heinich et al., (2002) also describes interactive multimedia as multimedia that allows students to make implementations and receive feedback (Arkun \& Akkoyunia, 2008). Interactive multimedia that can be used when learning must meet three criteria, namely valid, practical and effective. To produce this product, development research is carried out.

Multimedia is divided into two categories, namely linear multimedia and interactive multimedia. Linear multimedia is a multimedia that is not equipped with any controller that can be operated by the user. Examples are TV and movies. 
Meanwhile, interactive multimedia is a multimedia that is equipped with a controller that can be operated by users so that users can choose what they want for the next process. Examples include interactive learning media, game applications, etc. (Ariani and Haryanto 2010)

Based on observations made at SMA Barumun Tengah 1, Kabupaten Padang Lawas shows that there are problems with student learning outcomes. This is consistent with the average chemistry learning outcomes of students not meeting the minimum completeness criteria (KKM) set by the school where the KKM for chemistry subjects is 75 . Of the 25 students, only 10 people achieved the KKM score, or only about 33\% students who can understand the lesson well given.

In terms of student learning motivation in accordance with the results of interviews with chemistry teachers in class XI SMA 1 Barumun Tengah, Kabupaten Padang Lawas, it can be seen that there are several problems in the learning process including material presentation, most of which still use conventional methods and teachers are more oriented to transfer knowledge so less interesting and boring for students. This causes students to be passive in teaching and learning activities. To avoid this, the teacher can develop learning strategies by utilizing various media and learning resources (Sanjaya, 2007).

Student learning motivation can be analogized as a fuel to drive a machine, adequate learning motivation will encourage students to behave actively to excel in class, but too strong motivation can negatively affect the effectiveness of children's learning efforts (Oktaviana, 2011).

Learning outcomes are the results of the assessment given by the teacher to students in learning about the development and progress of students in schools relating to the mastery of subject matter. Learning outcomes in general can be grouped into three levels: low learning outcomes, intermediate learning outcomes and high learning outcomes (Dimyati, 2009)

Acquisition of learning outcomes between students is not the same because many factors influence the learning process. Learning outcomes achieved by students are influenced by two factors, namely the factors within students and external factors of students (Sudjana, 2001).

Research and development is a process or steps to develop a new product or perfect an existing product that can be accounted for (Sukmadinata, 2008). The product is not always in the form of objects or hardware, such as books, modules, student worksheets (LKS), but can also in software such as programs or applications, learning models, or learning methods. Development research which is usually called research based development is a type of research that is being increasingly used in solving practical problems in the world of research, especially education and learning research.

Salt hydrolysis material is a chemistry material for class XI SMA / MA which is in semester 2. This material in the 2013 curriculum is taught after the Acid and Bases chapter. Purba (2006) states that acidic reactions with bases forming salts are called neutralizing reactions. This discussion is related to the nature of the salt solution. The theory that explains the nature of the salt solution, the concept of hydrolysis. In the final section, we will discuss the formula that can be used to estimate the $\mathrm{pH}$ of saline solution based on the concentration and ionization constant of the acid or base forming.

According to Hidayatullah (2008) Adobe Flash is an software animation that can help visualize subject matter in the form of interactive learning animations. On the other hand, Pramono (2004) said that Adobe Flash is an software animation that is currently a software favorite and widely used by web designers to make the web more dynamic.

Therefore, it is very necessary for a learning model based learning media that can help students understand salt hydrolysis material in students so that the learning process is more active and developing. To help students make it easier to master salt hydrolysis material, the learning is very appropriate is learning by using problem-based learning. Trianto., (2009)

Problem based learning (PBL) is a situation where students are faced with the problem of incomplete information and questions that have no answer. This scenario is presented to ask students about how to solve problems, such as defining and describing problems, making hypotheses, tracing data, conducting experiments or research, developing solutions that suit the conditions of the problem and evaluating the solution so that the solution can (Toharudin, 2011).

\section{RESEARCH METHODS}

This type of research is Research and Development ( $\mathrm{R} \&$ $\mathrm{D})$. The product that will be developed in this study is in the form of interactive multimedia using program Adobe Flash for high school students of class XI on the subject of salt hydrolysis. Adobe Flash developed includes images, animation, display, practice questions and tests.

This research was carried out at SMA Barumun Tengah 1, Padang Lawas Regency. The research subjects were students of class XI even semester 2017/2018 school year. Sampling was done using purposive random sampling technique.

TABLE 1. Study Design

\begin{tabular}{|l|l|c|}
\hline \multirow{2}{*}{$\begin{array}{l}\text { Learning } \\
\text { Motivation }\end{array}$} & \multicolumn{2}{|l|}{ Models } \\
\cline { 2 - 3 } & $\begin{array}{l}\text { Problem based } \\
\text { learning }\left(\mathrm{A}_{1}\right)\end{array}$ & Direct Instruction $\left(\mathrm{A}_{2}\right)$ \\
\hline Height $\left(\mathrm{B}_{1}\right)$ & $\mathrm{A}_{1} \mathrm{~B}_{1}$ & $\mathrm{~A}_{2} \mathrm{~B}_{1}$ \\
\hline Low $\left(\mathrm{B}_{2}\right)$ & $\mathrm{A}_{1} \mathrm{~B}_{2}$ & $\mathrm{~A}_{2} \mathrm{~B}_{2}$ \\
\hline
\end{tabular}

Description:

$A_{1} B_{1}$ : The gain score is normalized by students who are taught PBL models by using interactive multimedia learning that has a high level of learning motivation

$\mathrm{A}_{1} \mathrm{~B}_{2}$ : Gain scores are normalized by students who are taught PBL models using interactive learning multimedia that have a low learning motivation level

$\mathrm{A}_{2} \mathrm{~B}_{1}$ : The gain score is normalized by students who are taught the DI model with using learning multimedia that has a high level of learning motivation 
$\mathrm{A}_{2} \mathrm{~B}_{2}$ : Gain scores are normalized by students who are taught DI models using learning multimedia that have a low level of learning motivation.

In the application of the teaching and learning process, classes are divided into two groups: experimental class using multimedia learning. interactive based on problem based learning by using program Adobe Flash that has been developed and control class using powerpoint media, both classes use the same learning model, PBL.

Trial procedures are presented in Figure 1.

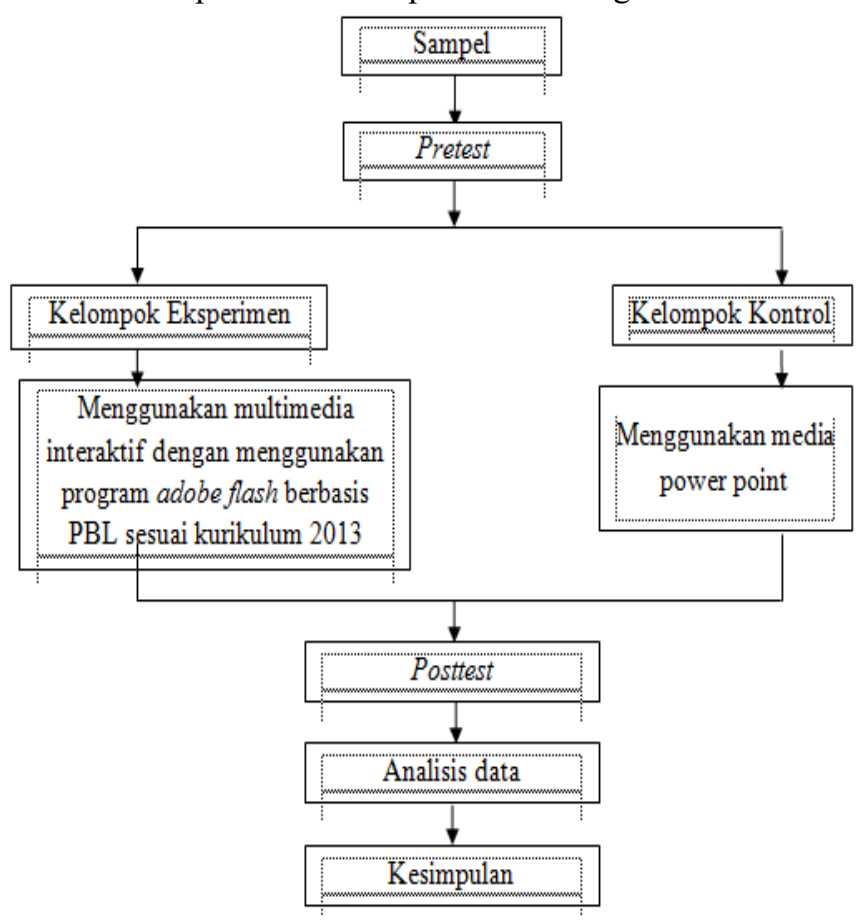

Fig 1. Research Procedure

\section{RESULTS AND DISCUSSION}

\section{A. Research Results}

The research that has been carried out aims to produce interactive learning problem-based learning based on the 2013 curriculum. The media developed in this material composition must be in accordance with the contents in the high school chemistry syllabus of class XI based on the 2013 curriculum. , obtained data in the form of development process and product testing.

The data described in this study included: (1) data on the acquisition of students' chemistry learning outcomes on salt hydrolysis material taught using powerpoint and taught with interactive media developed, (2) student learning motivation questionnaire acquisition data on the use of interactive based learning media problem based learning on hydrolysis material based on the 2013 curriculum.

\section{B. Research Results Data}

Before the sample was given a different treatment, the first two samples were given an initial test or pretest to determine the students' initial abilities. The questions used in the pretest were 20 questions. The results of pretest students in the experimental and control classes can be seen in Table 2 .

TABLE 2.Data Pretest StudentClass Experiments and Control

\begin{tabular}{ccccc}
\hline Class & Average & $\begin{array}{c}\text { Standard } \\
\text { Deviation }\end{array}$ & Highest & $\begin{array}{c}\text { Value } \\
\text { Lowest } \\
\text { Value }\end{array}$ \\
\hline Experiment & 24,60 & 7,76 & 40 & 10 \\
Control & 15,20 & 7,70 & 35 & 5
\end{tabular}

From Table 2. it can be seen that the average value of pretest the experimental class higher than in the control class, with the average pretest experiment was 24.00 and the pretest of the control class was 15.20.

Based on the data obtained from the research results obtained the average of thevalues posttest for the experimental class and control class are summarized in Table 3

TABLE 3. Data Posttest Student Class Experiment and Control

\begin{tabular}{ccccc}
\hline Class & Average & $\begin{array}{c}\text { Standard } \\
\text { Deviation }\end{array}$ & Highest & $\begin{array}{c}\text { Value } \\
\text { Lowest } \\
\text { Value }\end{array}$ \\
\hline Experiment & 86.00 & 6.61 & 95 & 75 \\
Control & 75.40 & 4.77 & 80 & 65
\end{tabular}

From the above table it can be concluded that the average value of posttest, experimental class the students that learned to use media interactive learning with PBL learning model was higher than the control class students taught using instructional media powerPoint learning model DI, with average posttest experiment is 86.00 and posttest control group was 75.40 .

Based on the results of the pretest and posttest can be known the level of students' understanding of salt hydrolysis by calculating normalized gain ( $\mathrm{N}$-gain). Description of $\mathrm{N}$ gain data for the experimental and control classes can be seen in Table 4.

TABLE 4. Data value N-gain Class Experiment and Control

\begin{tabular}{ccccc}
\hline Class & $\begin{array}{c}\text { Avera } \\
\text { ge }\end{array}$ & $\begin{array}{c}\text { Standa } \\
\text { rd } \\
\text { Deviati } \\
\text { on }\end{array}$ & Rated & $\begin{array}{c}\text { Lowest } \\
\text { Rated }\end{array}$ \\
\hline $\begin{array}{c}\text { Experiment } \\
\text { al } \\
\text { Control }\end{array}$ & 0.82 & 0.08 & 0.94 & 0.69 \\
& 0.71 & 0.04 & 0.79 & 0.63
\end{tabular}

Based on Table 4. shows that the N-gain of students in the subject of salt hydrolysis for the experimental class obtained an average $\mathrm{N}$-gain of 0.82 (average is high). Whereas for the control class, the average $\mathrm{N}$-gain is 0.71 (average is high).

Students from each class are grouped into two groups based on learning motivation data, namely high learning motivation groups and low learning motivation groups. The description of learning motivation data in both classes can be seen in Table 4 
TABLE 5.Deskripsi student motivation Data

\begin{tabular}{cccccc}
\hline Class & N & $\begin{array}{c}\text { Aver } \\
\text { age }\end{array}$ & $\begin{array}{c}\text { Standar } \\
\text { d } \\
\text { Deviatio } \\
\text { n }\end{array}$ & $\begin{array}{c}\text { Mini } \\
\text { mum }\end{array}$ & $\begin{array}{c}\text { Maxi } \\
\text { mum }\end{array}$ \\
\hline Experiment & 2 & 75.92 & 5.36 & 67.00 & 90.00 \\
& 5 & & & & \\
Control & 2 & 69.64 & 9.54 & 40.00 & 85.00 \\
& 5 & & & & \\
\hline
\end{tabular}

Based on student learning motivation out of a total of 50 students, 21 students had high learning motivation (as many as 15 from the experimental class and 6 from the control class). While as many as 29 students were classified as low (as many as 10 from the experimental class and 19 from the control class). This shows that students' learning motivation using motivation questionnaire data is higher than the control class.

\section{Research Data Analysis Data Normality Test Normality}

tests are conducted to determine whether the distributed data used has been normally distributed or not. Normality of the data was tested by thetechnique Kolmogorov-Smirnov Test. Data is declared normal if the probability value or sig $>$ 0.05 . The results of normality tests for experimental and control students are shown in Table 6 .

TABLE 6. Normality Test Results Experimental Class Data andControl

\begin{tabular}{|c|c|c|c|c|}
\hline ClassClass & Data & Sig & $\alpha$ & Description \\
\hline \multirow[t]{5}{*}{ Experiment } & Pretest & 0.273 & 0.05 & $\begin{array}{l}\text { Data normally } \\
\text { distributed }\end{array}$ \\
\hline & Posttest & 0.486 & 0.05 & $\begin{array}{l}\text { Data normally } \\
\text { distributed }\end{array}$ \\
\hline & $\mathrm{N}$-gain & & & Data normally \\
\hline & Learning & 0.924 & 0.05 & distributed \\
\hline & $\begin{array}{l}\text { motivatio } \\
\mathrm{n}\end{array}$ & 0.845 & 0.05 & $\begin{array}{l}\text { Data normally } \\
\text { distributed }\end{array}$ \\
\hline \multirow[t]{4}{*}{ Control } & Pretest & 0.141 & 0.05 & $\begin{array}{l}\text { Data normally } \\
\text { distributed }\end{array}$ \\
\hline & Posttest & 0.05 & 0.05 & $\begin{array}{l}\text { Data normally } \\
\text { distributed }\end{array}$ \\
\hline & $\begin{array}{l}\text { N-gain } \\
\text { Learning }\end{array}$ & 0.730 & 0.05 & $\begin{array}{l}\text { Data normally } \\
\text { distributed }\end{array}$ \\
\hline & $\begin{array}{l}\text { moti } \\
\text { vatio } \\
\mathrm{n}\end{array}$ & 0.307 & 0.05 & $\begin{array}{l}\text { Data normally } \\
\text { distributed }\end{array}$ \\
\hline
\end{tabular}

Based on Table 6 it can be seen that the data pretest, posttest and $\mathrm{N}$ - the experimental class and the control class have a probability value $>\alpha 0.05$, it can be concluded that thedata pretest, posttest and N-gainare normally distributed.

\section{Homogeneity Test Data Homogeneity}

test is done to find out whether the two sample groups have the same initial (homogeneous) ability. Data were tested usingtechnique Levene's Test or F Test using SPSS 20.0. Homogeneity testing was performed on thedata of the pretest and posttest two sample groups. Data is stated to have the same (homogeneous) variance if the sig value. $>0.05$. The results of testing the homogeneity of the data can be seen in Table 7.

TABLE 7. Data homogeneity test results of experimental class and control class

\begin{tabular}{ccccc}
\hline Data & \multicolumn{1}{c}{ Sig } & \multicolumn{1}{c}{$\boldsymbol{\alpha}$} & \multicolumn{1}{c}{ Information } \\
\hline Pretest & 0.880 & 0.05 & Homogeneous data \\
\hline Posttest & 0.087 & 0.05 & Homogeneous data \\
\hline Ngain & 0.366 & 0.05 & Homogeneous data \\
\hline
\end{tabular}

Based on Table 7 it can be seen that thedata pretest and posttest from both classes were sampled research from homogeneity testing results with thetechnique Levene's Test, sig values are obtained. $>0.05$ can be concluded that the two sample groups (class experiment and control class) come from a homogeneous population.

\section{Hypothesis Testing}

After the prerequisites for data analysis are fulfilled both the normality and homogeneity of the data, it can be tested hypotheses. The sample group that measured the improvement of learning outcomes based on the N-gain value and students' learning motivation were grouped into high learning motivation and low learning motivation based on the questionnaire given at the final learning meeting.

The results of hypothesis testing using two-way variance analysis (ANAVA) technique with the help of SPSS 20.0 program are summarized in Table 8.

TABLE 8. Results of analysis of variance analysis (ANAVA) two lines

\begin{tabular}{ccccc}
\hline Source & $\begin{array}{c}\text { Total } \\
\text { Squares }\end{array}$ & $\begin{array}{c}\text { Average } \\
\text { Squares }\end{array}$ & F & Sig \\
\hline Constants & 24,317 & 24,317 & $\begin{array}{c}171184, \\
226\end{array}$ & $\begin{array}{c}0,00 \\
0\end{array}$ \\
\hline \begin{tabular}{c|c|c|c} 
Model_ \\
Learning
\end{tabular} & 0.54 & 0,54 & 38,200 & $\begin{array}{c}0,00 \\
0\end{array}$ \\
\hline Learning & 0,117 & 0,117 & 82,352 & $\begin{array}{c}0,00 \\
0\end{array}$ \\
Motivation & & & & 0 \\
\hline
\end{tabular}

Motivation

Based on Table 8 it can be seen that the learning model applied give effect to student learning outcomes as indicated by the significance price of $0,000<0,05$ means that $H_{a}$ is accepted and $\mathrm{H}_{\mathrm{o}}$ is rejected. The level of learning motivation gives a significant influence of $0.000<0.05$, meaning that $\mathrm{H}_{\mathrm{a}}$ is accepted and $\mathrm{H}_{\mathrm{o}}$ is rejected.

\section{Differences in student learning outcomes Differences in learning}

outcomes taught with PBL-based interactive learning multimedia andlearning media powerpoint DI- 
basedusingprogram SPSS 20.00 for windows is presented in Table 9.

TABLE 9. The results of the average N-gain based on the results of the evaluation of learning in the teaching of salt hydrolysis.

\begin{tabular}{|c|c|c|c|}
\hline \multicolumn{1}{c}{$\begin{array}{c}\text { Multimedia } \\
\text { Learning }\end{array}$} & average & \multicolumn{2}{c}{ Interval Confidence 95\% } \\
\cline { 3 - 4 } & & Limits & Limits \\
\hline $\begin{array}{c}\text { Multimedia } \\
\text { Interactive } \\
\text { Learning } \\
\text { Based PBL }\end{array}$ & 0.802 & 0.787 & 0.817 \\
Multimedia & & & \\
Interactive \\
Learning \\
Based IN
\end{tabular}

The difference in the effect of multimedia interactive learning based PBL and learning multimedia inetraktif based DI on student learning outcomes are shown in Fig 2 .

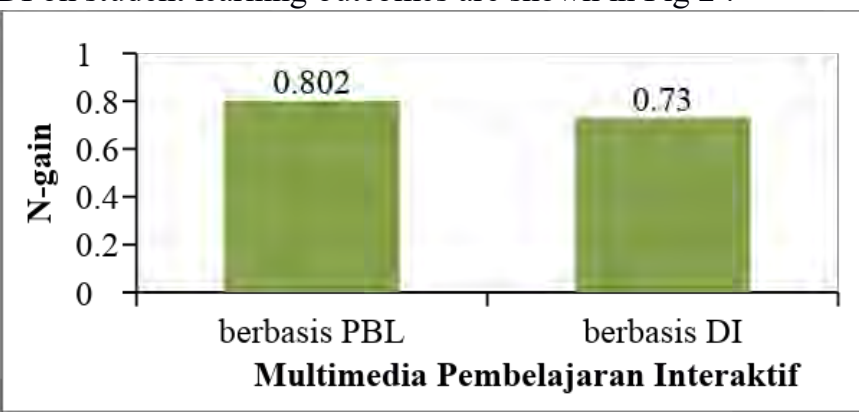

Fig 2. Graph of N-gain averages learned by PBL-based interactive learning multimedia andlearning multimedia powerpoint -based.

First Hypothesis: Differences in student learning outcomes

When viewed from the learning outcomes obtained in the experimental class with the control class, there are differences in learning outcomes based on learning motivation. Differences in student learning outcomes at the level of learning motivation are presented in Table 10.

TABLE 10. The results of the average N-gain are based on motivation (high and low) on chemistry teaching.

\begin{tabular}{|ccc|c|}
\hline \multirow{2}{*}{$\begin{array}{c}\text { Learning } \\
\text { Motivation }\end{array}$} & Average & \multicolumn{2}{c}{ Trust Interval 95\% } \\
\cline { 3 - 4 } & \multicolumn{2}{c}{ Low } & $\begin{array}{c}\text { Limit } \\
\text { Highest }\end{array}$ \\
\hline Height & 0.819 & 0.786 & 0.852 \\
\hline Low & 0.653 & 0.626 & 0.680 \\
\hline
\end{tabular}

Differences in the influence of motivation levels on learning outcomes are shown in Fig 3.

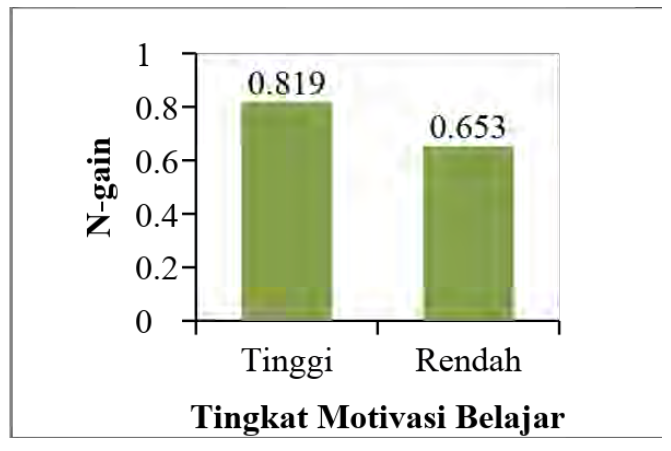

Fig 3. Graph of N-gain averages based on learning motivation

\section{Discussion}

The findings of the research show that for the experimental class students who are taught with PBL-based interactive learning media have an average $\mathrm{N}$-gain of 0.802 higher than the control class students who are taught by the DI model that has the average $\mathrm{N}$-gain value is 0.730 .

The difference in learning outcomes obtained between the experimental class and control class is because during the learning process in the classroom shows that overall using PBL-based interactive learning media makes students more active in the learning process starting from understanding the problems posed by the teacher in the learning media, active discuss and ask questions, and want to work on the questions given by the teacher. In addition, students also have more confidence, are open, eager, willing to cooperate and respect the opinions of other students.

Meanwhile, for groups of students who were taught withlearning media powerpoint -basedbased on DI, during the learning process students were more silent by only listening and paying attention to the explanations given by the teacher in front of the class. The learning process only runs one direction from the teacher as the material giver to the student as the recipient of the material. Learning activities are also more dominated by teacher activities (teacher-centered) in delivering subject matter. During the learning process students only listen, record important things from the teacher's explanation individually. Some students also seemed to lack enthusiasm to take part in ongoing learning and were more focused on making notes and memorizing.

Data on students' level of learning motivation is obtained from the results of questionnaires filled by students at the end of the learning meeting. Based on learning motivation data, students are grouped into two groups: groups that have students who have high learning motivation and groups of students who have low learning motivation.

The average value of $\mathrm{N}$-gain learning outcomes of students who have a high level of learning motivation is different from the N-gain of students' learning achievement level of learning motivation is low. The results of the average $\mathrm{N}$-gain obtained by students at the level of high student learning motivation is 0.819 higher than the average $\mathrm{N}$-gain level of student learning motivation is low at 0.653 .

The results of the study show that student learning motivation affects learning outcomes. Students who have high 
learning motivation tend to show enthusiasm and excitement in participating in learning activities.

\section{CONCLUSION}

\section{Conclusion}

There are differences in learning outcomes through PBLbased interactive learning multimedia andlearning media powerpoint DI-based. There are differences in learning outcomes through PBL-based interactive learning multimedia andlearning media powerpoint DI-based at high and low motivation levels.

\section{Suggestion}

Schools should be more complete facilities to support the learning process and utilize the facilities that have been available to the maximum so that students get maximum learning achievement. For further researchers who will conduct similar research can develop interactive multimedia using Adobe Flash based on other learning models on other materials with regard to the suitability of the material with learning needs.

\section{ACKNOWLEDGMENT}

Praise and thankfulness of the writer to Allah SWT, for all His blessings and blessings, this research can be completed properly. This research is entitled "thedevelopment of interactive learning multimedia using adobe flash program based on problem based learning to improve motivation and student learning outcomes in salt hydrolysis material". On this occasion the author would like to thank: Mr. Dr. Ajat Sudrajat, M.Sc, as a supervisor who has provided guidance and suggestions to the author since the beginning of the research until the completion of this research. A big thank you to the principal, deputy headmaster, chemistry teacher and students of class XI IPA ${ }^{1}$ and XI IPA ${ }^{2}$ Barumun Tengah 1 State Senior High School who have helped the writer during the research process.

\section{REFERENCES}

[1] Ariani, Niken and Dany Haryanto. 2010. Multimedia Learning in Schools. Jakarta. Pustakarya Achievement.

[2] Arkun and Akkoyunia. 2008. A Study on The Development Process of A Multimedia Learning Environment According to The Addie Model and Students' Opinions of the Multimedia Learning Environment. Interactive Educational Multimedia: Universty of Barcelona, 10 (17)

[3] Arsyad, A. 2011. Learning Media. Jakarta. Raja Grafindo Persada

[4] Basri, Irma Yulia. 2013. Utilization of Multimedia Animation in Engineering Courses to Increase
Students' Understanding of the Chemical Bond Concept. Thesis, ISSN: 2086 - 4981

[5] Dimyati. 2009. Learning and Learning. Jakarta. Rineka Cipta Publisher.

[6] Heinich, R., Molenda, M., and Russell, JD 2007. Instructional Media and Technology for Learning. New Jersey. Prentice Hall, Inc.

[7] Hidayatullah, Priyanto. 2008. Making Educational Animation using Flash. Bandung. Informatics.

[8] Kirna, I M. 2010. Determination of the Proportion of Learning Understanding of Chemical Concepts through the Implementation of Synchronization Learning in Macroscopy and Sub-microscopy Studies. Journal of Education and Teaching, 43 (3)

[9] Oktaviana, MA ,. 2011. The Influence of the Use of Hydrocarbon Card Media Packages Against Motivation and Chemistry Learning Outcomes of Class X Semester Even High School Students in Bantul Yogyakarta Academic Year 2012/2013. Essay. Yogyakarta. UIN - SUNAN KALIJAGA

[10] Purba, M. 2006. Chemistry 2 for High School Class XI. Jakarta. Erlangga.

[11] Pusparini, HLP 2009. Development of Learning Programs for Chemistry of Atomic Structure Computer Based Interaction. Essay. Singaraja. University of Education Ganesha

[12] Rahmawati, Y. 2006. CD Effectiveness Interaction as a Chemistry Learning Media The Subjects of Compound and Equation Names Simple Record Class X Semester I Teuku Umar High School Semarang 2005/2006 Academic Year. Essay. Semarang. UNESA

[13] Sanjaya, W. 2007. Planning and Design of Learning Systems. Jakarta. Kencana.

[14] Sirodjuddin, A. 2007. The Effectiveness of the Use of Interactive Computer Assisted Programs to Improve the Quality of Chemistry Learning at SMK Negeri 8 Semarang. Semarang. UNESA

[15] Sudarsana, I M. 2010. Making Interactive Learning Programs Computer Assisted Reaction Rates forChemistry Learning High School. Essay. Singaraja. University of Education Ganesha

[16] Sudjana. 2001. Statistical Method. Tarsito Publisher. Bandung.

[17] Sudria, IB. N. 2006. Development of Chemistry Education Materials in Junior High School in the Framework of Education "Science For All". Dissertation. Bandung.UPI

[18] SPSSukmadinata, NS 2008. Educational Research Methods. Bandung. PT Remaja Rosdakarya

[19] Toharudin, Uus. 2011. Building Science Literacy for Students. Bandung. Humanities.

[20] Trianto. 2010. Designing Innovative-Progressive Learning Models. Jakarta. Kencana 